\title{
Left-sided inferior vena cava
}

\author{
Mototsugu Matsunaga, Masaru Fukahori, Tomoyuki Ushijima, Keisuke Miwa
}

Multidisciplinary Treatment Cancer Center, Kurume University Hospital, Kurume, Japan

\section{Correspondence to} Dr Mototsugu Matsunaga, mmandmacgyver@yahoo.co.jp

Accepted 25 May 2015

\section{DESCRIPTION}

A middle aged man underwent sigmoidectomy and hepatic metastasis resection for sigmoid cancer and hepatic metastases, respectively. Subsequently, hepatic arterial infusion therapy was performed for recurrence after the hepatic metastasis resection. However, no local control was obtained, and metastasis occurred at a site other than the liver, namely, the diaphragm. Therefore, the patient was referred to our department for systemic chemotherapy.

Abdominal CT performed on referral to our department (figures 1 and 2) showed the left-sided inferior vena cava ${ }^{1}$ ascending on the left side of the abdominal aorta. The left and right common iliac veins joined together and formed the left-sided inferior vena cava running to the right side of the abdominal aorta with the left and right renal veins. Sigmoidectomy was performed without any intraoperative problems, and the left-sided inferior vena

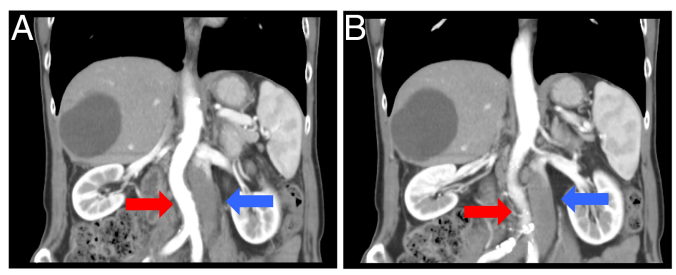

Figure 1 Abdominal CT scans showing the left-sided inferior vena cava (blue arrow) ascending on the left side of the abdominal aorta (red arrow). cava did not show any symptoms. The left-sided inferior vena cava, which was accidentally detected with sigmoid cancer, is a relatively rare anomaly ${ }^{12}$ and a considerably interesting imaging finding.

\section{Learning points}

- Anomalies of the inferior vena cava system manifest in various forms depending on the process of development. In this case, the left-sided inferior vena cava was accidentally detected on an abdominal CT scan.

- In few cases, a left-sided inferior vena cava causes clinical symptoms. However, when thrombosis is observed, this condition should be included in the differential diagnosis.

Competing interests None declared.

Patient consent Obtained.

Provenance and peer review Not commissioned; externally pee reviewed.

\section{REFERENCES}

1 Hoeltl W, Hruby W, Aharinejad S. Renal vein anatomy and its implications for retroperitoneal surgery. J Urol 1990;143:1108-14.

2 Reis RH, Esenther $\mathrm{G}$. Variations in the pattern of renal vessels and their relation to the type of posterior vena cava in man. Am J Anat 1959;104:295-318.
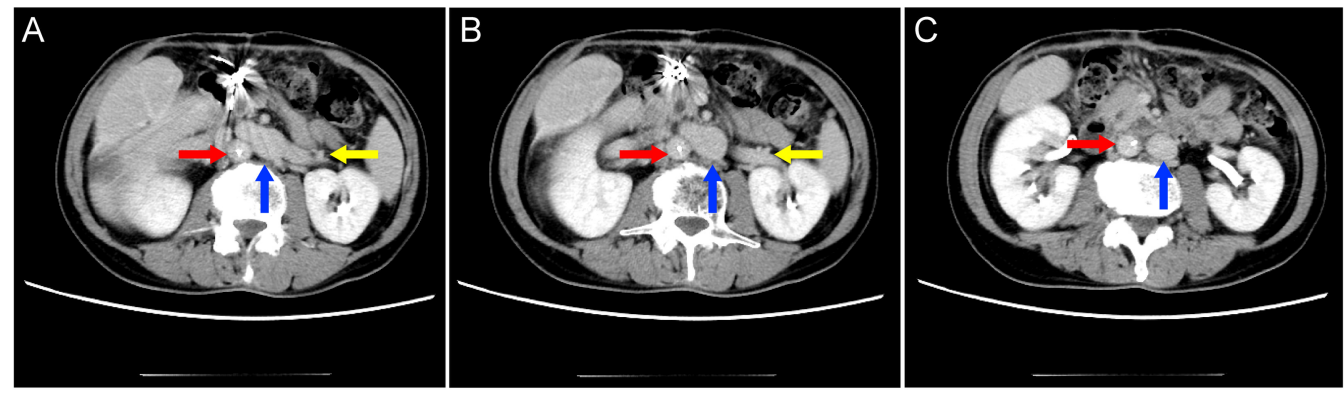

Figure 2 Abdominal CT scans showing the left-sided inferior vena cava (blue arrow) ascending on the left side of the abdominal aorta (red arrow). The left renal vein (yellow arrow) joins the left-sided inferior vena cava. A catheter is placed in the abdominal aorta for hepatic arterial infusion therapy.

CrossMark

To cite: Matsunaga $\mathrm{M}$, Fukahori M, Ushijima T, et al. BMJ Case Rep Published online: [please include Day Month Year] doi:10.1136/bcr-2015211268 


\section{Images in...}

Copyright 2015 BMJ Publishing Group. All rights reserved. For permission to reuse any of this content visit http://group.bmj.com/group/rights-licensing/permissions.

BMJ Case Report Fellows may re-use this article for personal use and teaching without any further permission.

Become a Fellow of BMJ Case Reports today and you can:

- Submit as many cases as you like

- Enjoy fast sympathetic peer review and rapid publication of accepted articles

- Access all the published articles

- Re-use any of the published material for personal use and teaching without further permission

For information on Institutional Fellowships contact consortiasales@bmjgroup.com

Visit casereports.bmj.com for more articles like this and to become a Fellow 